\title{
PHILOLOGY
}

\section{ТЕРМІНИ-ПАРОНІМИ ТА ПИТАННЯ КУЛЬТУРИ НАУКОВОГО МОВЛЕННЯ}

канд. філол. наук Нечипоренко Алла

Україна, Київ, КПІ ім. Ігоря Сікорського

DOI: https://doi.org/10.31435/rsglobal_sr/28022020/6956

\section{ARTICLE INFO}

Received 14 December 2019 Accepted 06 February 2020

Published 28 February 2020

\section{KEYWORDS}

Ukrainian language, linguistic terminology, paronyms, culture of speech, scientific discourse.

\begin{abstract}
The article deals with the issue of the culture of the Ukrainian scientific text, in particular, the difficulty in ensuring accuracy as a communicative feature of speech due to paronyms in terminology of various sciences; it also outlines the views of modern linguists on this lexical and semantic phenomenon, presents the definitions available in the scientific literature, analyzes semantic and structural features of these units, the ways of creating them and distinguishing between them, and illustrates the classification characteristics of full and partial paronyms by the example of linguistic terminology.
\end{abstract}

Citation: Нечипоренко Алла. (2020) Terminy-Paronimy ta Pytannia Kultury Naukovoho Movlennia. Science Review. 2(29). doi: 10.31435/rsglobal_sr/28022020/6956

Copyright: (C) 2020 Нечипоренко Алла. This is an open-access article distributed under the terms of the Creative Commons Attribution License (CC BY). The use, distribution or reproduction in other forums is permitted, provided the original author(s) or licensor are credited and that the original publication in this journal is cited, in accordance with accepted academic practice. No use, distribution or reproduction is permitted which does not comply with these terms.

Вступ. Мовленнєвим законом, що є одним 3 основних для наукового мовлення, передбачено відповідність тексту системі комунікативних ознак, серед яких, на думку професора П.О. Селігея, головними для наукового мовлення є логічність, стислість, точність, ясність; потрібними: об'єктивність, зв'язність, виразність, дієвість, дохідливість, достатність, змістовність, послідовність, пропорційність, структурованість, цілеспрямованість, доречність, правильність, чистота; допустимими: експресивність, багатство, естетичність, образність, ритмічність, різноманітність [4, с.13]. Точність як ознака вбачає уживання мовних одиниць у звичних значеннях, недвозначність мовлення; сувора відповідність між змістом і мовними засобами. До типових помилок на шляху досягнення високої культури мовлення належить не завжди чітке розрізнення термінів-паронімів, які стосуються як загальнонаукової проблематики, так і міжгалузевої /вузькоспеціальної.

Паронімія як лексичне та стилістичне явище стала предметом дослідження вітчизняних та зарубіжних науковців Д. Г. Гринчишина, О. А. Сербенської, В. Ващенка, О. Вишнякової,
Т. В. Веракши
Ю. А. Бєльчикова,
А. В. Юханова,
Ю. П. Люстрової,
О. І. Голованової,

М. С. Панюшева, . І. Красних, А. Н. Гвоздєва, . П. Колеснікова, В. М. Штибіна, О. П. Антипінної, М. Т. Демського та ін. Пароніми у складі термінологічного словника аналізували у статтях такі мовознавці, як С. Булик-Верхола - у музичній термінології, Т. Луковенко - у гомеопатичній термінології, О. Тодор - у політологічній терміносистемі; I. Мягкота у сфері фольклористики, О.Тур - у термінології землеустрою та кадастру, у сфері філології М.Баган. Окремого грунтовного дослідження явища паронімії в українському мовознавстві й досі немає. Лексикографічним здобутком українського мовознавства є «Словник паронімів української мови», який уміщує тисячу лексем, укладених за абетковим принципом. У передмові до видання українські мовознавці Д.Г.Гринчишин та О. А. Сербенська дають прийнятне науці визначення: пароніми - слова дуже близькі за звучанням, але різні за значенням і написанням [2, с. 9]. За енциклопедією «Українська мова», «...пароніми - слова, а також 
фразеологічні одиниці й синтаксичні конструкції, що при повній чи частковій семантичній відмінності є дуже подібними за формою, унаслідок чого можуть сплутуватися у мовленні [6, с. 425]. За вужчого розуміння поняття до паронімів можемо віднести однокореневі слова, що належать до однієї частини мови, подібність у морфемному складі зумовлює, відповідно, їхню семантичну подібність, наприклад: найчастіше у них різні суфікси [там само]. Словник паронімів постійно поповнюється, а відтак зростає потреба в їх описі та аналізі.

Мета наукової розвідки - проаналізувати особливості паронімічних відношень між термінами мовознавчого дискурсу. Метою передбачається виконання таких завдань: виокремити терміни-пароніми та скласифікувати їх за семантичними та структурними ознаками.

Результати дослідження. На думку мовознавця М. Вакуленка, ...терміни є звичайними словами, а відтак і для них характерні ті самі відношення, що й до інших лексичних одиниць розрізнення за значенням та приналежніть до різних лексичних категорій [1]. Так, у розділі «Основні лексико-семантичні відношення в термінолексиконі» монографії дослідник зазначає, що «на відміну від омонімії, яка $є$ явищем випадковим, паронімія становить певного типу закономірність, пов'язану, зокрема, з різноманіттям і різноплановістю афіксальної системи флективних мов, в тому чисті й української. Автор упевнений, що паронімія виявляє багатство морфологічних тактик у мові та засвідчує здатність мови виражати широкий спектр семантичних нюансів [1, с. 46]. Мовознавець вважає, що доцільно розглядати два типи паронімів: 1) такі, що за формальної схожості мають суттєві семантичні відмінності; 2) семантика яких не має принципових розбіжностей, а відповідні афікси засвідчують певні відтінки основних значень [там само].

Розглянемо терміни-пароніми у складі мовознавчої наукової лексики, узявши цю класифікацію за основу. Такі одиниці можуть стосуватися категорії загальнонаукових термінів: об'єкт - суб'єкт, об'єкт - пізнавана дійсність, що існує поза свідомістю людини і незалежно від неї; суб'єкт - істота, здатна до пізнання навколишнього світу, об'єктивної дійсності й до цілеспрямованої діяльності. (СУМ) Серед міжгалузевих термінів: степінь-ступінь, де ступінь порівняльна величина, що характеризує розмір, інтенсивність, міру вияву чого-небудь: ступінь порівняння; - разом з числівником означає певний розряд, категорію; степінь - математичний термін: добуток декількох однакових співмножників: піднести до степеня. Або ж термін 3 економічної/мовознавчої терміносистем: артикул (узагальнений показник, що характеризує основні функціональні та якісні властивості товару) - артикль (службове слово, яке вживається 3 іменем для позначення роду, числа, відмінка в деяких мовах); та вузькоспеціальних: мова мовлення, де мова - здатність людини говорити: відібрало мову, — манера висловлювання: езопівська мова; - система звукових, лексичних та граматичних одиниць, якими послуговується певний народ для письмового та усного спілкування: українська мова, а мовлення - спілкування за допомогою мови, уміння висловлювати власну думку.

За стильовою значенням приналежністю помітними є групи паронімів, де один компонент - спеціальне слово, а друге є загальновживаним: вид (граматична категорія, що характеризує дію і стан з погляду їх тривання, становлення, розгортання, результативності, завершеності в часі; вигляд (сукупність зовнішніх ознак, особливостей кого-, чого- небудь, що створює відповідне враження $(1$, с.371, с.381)

За структурою пароніми бувають префіксальні, суфіксальні та кореневі, домінує в цьому розподілі суфіксальний різновид: діалектний (прикм. до діалект) - діалектологічний (прикм. до діалектологія); комунікативний (що стосується комунікації як спілкування), а комунікаційний (стосується шляхів сполучення), стильовий (який стосується стилю) стилістичний (пов'язаний з прийомами та нормами використання мовних засобів).

За граматичним значенням пароніми належать до лексико-граматичного класу іменника та прикметника, здебільшого похідних від іменникових: омофони-омоформи, словотвірнийсловотворчий, склад-складник, множина-множинність, фонетичний-фонематичний..

Явище паронімії поширене як серед власне українських слів, так і серед запозичених та похідних від них: говір - говірка, вид-вигляд, морф-морфема, номіначія-нумералізачія, акиентологія - акиентуація, евфемізм-дисфемізм.

Розрізняють паронімію максимальну, абсолютну або істинну (повну) й неповну, часткову.

До повної паронімії належать співзвучні слова, близькі за своєю семантикою, які мають однакову кореневу частину. 
У досліджуваній групі співзвучної лексики, якими є неповні пароніми, можна виділити різні типи:

1) консонантний тип - зміни відбуваються у складі групи приголосних:

пароніми-патроніми, епонім--етнонім, синтетизм-синкретизм, графіка-графіті;

2) вокалічний тип - зміни відбуваються у складі голосних:

перифраз-парафраз, степінь-ступінь, галицизм - галліцизм;

3) аугментативний, коли звукова подібність досягається нарощуванням звуків по обидва боки від основного кореня слова: морф - аломорф, вербалізація-адвербалізація.

У паронімічні відношення можуть вступати також близькозвучні слова (найчастіше спільнокореневі), у яких процес розмежування за значенням повністю не завершився: в окремих значеннях вони розмежовуються, в інших - зближуються, вступаючи навіть у синонімічні зв'язки., наприклад питання-запитання: запитання це словесне звернення, яке потребує відповіді. Запитанням може називатися і звернення, яке не потребує відповіді. Це так зване риторичне запитання - художній засіб образної мови. Слово питання здебільшого вживають, коли йдеться про якусь проблему, справу, що потребує розв'язання або вивчення.

Висновки. Отже, пароніми можуть створювати семантичний бар'єр у спілкуванні та стати причиною помилок в усній та писемній формі академічних текстів. Звукова близькість i незначна різниця у вимові паронімів спричиняє труднощі в їх засвоєнні та призводить, на думку мовознавця О. Пономарева, до «неприпустимого вживання їх один замість одного, що затемнює зміст висловлювання» [5, с. 82]. Такі порушення спотворюють текст, тому науковець/промовець несе відповідальність за якість своєї роботи, а тому має самостійно оперувати матеріалами з перевірених наукових лексикографічних джерел.

\section{ЛІТЕРАТУРА}

1. Вакуленко М. Українська термінологія: комплексний лінгвістичний аналіз. Івано-Франківськ: Фоліант, 2015. $361 \mathrm{c.}$

2. Гринчишин Д.Г., Сербенська О.А. Словник паронімів української мови. К.: Радянська школа, 1986. 222 с.

3. Пономарів О. Культура мови: мовностилістичні поради. К.: Либідь, 2001. С.82-108.

4. Селігей П.О. До проблеми комунікативних якостей наукового мовлення. Мова. 2016. № 25. С. 11-17.

5. Словник української мови: в 11 тт. / АН УРСР. Інститут мовознавства; за ред. І. К. Білодіда. К.: Наукова думка, 1970-1980.

6. Українська мова. Енциклопедія. Київ.: «Українська енциклопедія» ім. М. П. Бажана, 2000. 750 с. 